\title{
Pelargonium Peltatum Oil
}

National Cancer Institute

\section{Source}

National Cancer Institute. Pelargonium Peltatum Oil. NCI Thesaurus. Code C72209.

The essential oil extracted from the leaves of the ivy-leaved geranium, Pelarg onium peltatum. Pelargonium peltatum is used primarily in parfumery. 